\section{(xin $\operatorname{nthropological~gtudy~}$}

\section{SOME PORTRAI'IS OF SHAKESPEARE AND OF BURNS.}

By ARTHUR KEITH, M.D., F.R.S.,

COASERVATOR OF THE MESECM, ROYAL COLLEGE OF SCRGEONS, ENGLAND; PRESIDENT OF THE ANTHROPOLOGICAL INSTITUTE.

[With Special Plate.]

I became interested in the buist and numerous portraits of Shakespeare in the following manner: Three years ago Mr. H. Oatway came to the Museum of the Royal College of Stirgeons, bringing with him a terra-cotta mask he had discovered in the shop of a curio dealer in one of the English Midland counties. The mask t represented the features of Shakespeare-those features with which the monument at Stratford-on-Avon has made us familiar. There were numerous differénces in detaif when the bust and nask were compared, and the question had arisen whether the newly-discovered mask might not be a squeeze-a modelled up squeeze was the term Mr. Konody used in his description-from the cast which is said to have been taken from Shakespeare's face aftér death. ${ }^{1}$ To assist ne in settling the problem, Mr. Oàtway helped in every way; he placed at my disposal measurements of the original bust at Stratford, two casts made from the bust, one of them bearing the well-known Bullock cast; and he obtained photographs of the various portraits and busts which are believed to represent Shakespeare. My investigations of the Oatway mask yielded only negative results. As in the original bust, the eyes are open, the eyelids and eyeballs are modelled on conventional lines, the lips are full, slightly parted, and shaped so as to represent the condition in life. Neither the original bust nor the Oatway mask show any trace or mark of having been taken from a cast or model of a dead man's face. It was. also plain that there was a direct genetic relationship between the original bust and the Oatway mask, for every curl in the hair of the original bust was accurately reproduced in the terra-cotta mask. The features of the original-the Stratford-bust appear to me to be modelled about 10 per cent. above the dimensions of an average Englishman's face. In Mr. Oatway's mask the features come within the normal range. In particular, the nose is smaller and more compressed than in the original; in taking a death mask, the nose and lips are alivays compressed by the weight of the plaster. We also found, however, that a terra-cotta mask shrinks as it dries, and its various parts do not shrink equally. Although the origin of. Mr. Oatway's mask cannot be regarded as finally settled, yet it is not unlikely that it represents a cast from the monument at Stratford-on-Avon, and that its peculiarities are due to unequal shrinkage. In this manner I was introduced to the mysteries of shakespeare's portraits.

It was a fortunate circumstance that at the time I was investigating Mr. Oatway's mask Mr. M. H. Spielmann * was finishing a systematic examination of the evidence relating to the history of the monument at Stratford-onAvon, and to the authenticity of the numerous portraits of Shakespeare. His final opinion is that only the monument itself and the Droeshout portrait can be regarded as well authenticated-as having been in existence soon after Shakespeare's death in 1616. As regards the monument, even Mr. Spielmann has reservations; he is of opinion that its sculptor, Gerrard Johnson, "evolved"" the head and neck, and that there is an inconsistency between the proportions of the head and face. In his expiting book entitled Bacon is Shakespeare, Sir E. Durnipg-Lawrence refuses to regard either the monument or the Droeshout portrait as an authentic document. As regards the portrait, he has written ${ }^{2}$ :

It is almost inconceivable that people with eres to see shonld have looked at the só-called portrait for 287 years without perceiving that it consists of a ridiculous, putty-faced mask fixed upon a stuffed dunmy, clothed in a thick coat.

*Abstract of evening discourse at the Royal Institution, February 20th, 1914 .

tThe mask is described and figured by Mr. P. G. Konody in the Illustrated London News, July 17th, 1911.

the Spielmann is now preparing for publication a work which his essay revrinted from the Stratford edition.
The monument, in Sir Edwin's opinion, represents a flat-headed Chinaman, and was made, he believes, more than a century after Shakespeare's death. The doubts cast on the authenticity of the monument, first by Mrs. Stopes ${ }^{3}$ and later by Sir Edwin Durning-Lawrence, have been cleared away by the late Mr. Andrew Lang, ${ }^{4}$ and by lectures given at the Royal Institution by Mr. M. H. Spielmann in the same year. Anything we can know concerning the personal appearance, and of the racial character of the greatest Englishman has to be gathered from these two sources: the monument at Stratford-onAvon, and the Droeshout portrait Two other documents relating to Shakespeare have a special interest for me. One of these is the Davenant bust now in the Garrick Club, London. It was discovered in 1849, when the Duke's Theatre in Portugal Row, Lincoln's Inn Fields, was demolished to make room for an extension of tho Museum of the Royal College of Surgeons. It was at one time in the possession of my predecessor, Sir Richard Uwen. In the same year (1849) Dr. Becker came from Germany bringing with him the "Kesselstadt mask " of Shakespeare, which he submitted to Owen for examination. I do not think that either the bust or the mask can be regarded as "original documents."

If, then, we are to know the outward appearance of Shakespeare-to measure those characters of the head which are of particular interest to students of the human body-we must deduce them from either the Droeshout portrait or the Stratford monument. If the bust represented on the monument is largely imaginary, then tho blunders of the sculptor will become manifest when wo apply to it the various criteria which are used when heads and skulls are examined by modern anthropological methods. The remarkable dimensions which the sculptor of the Stratford bust has given to Shakespeare's head become manifest when an exact drawing is made of the crown from above (Fig. 1). Within a drawing of the

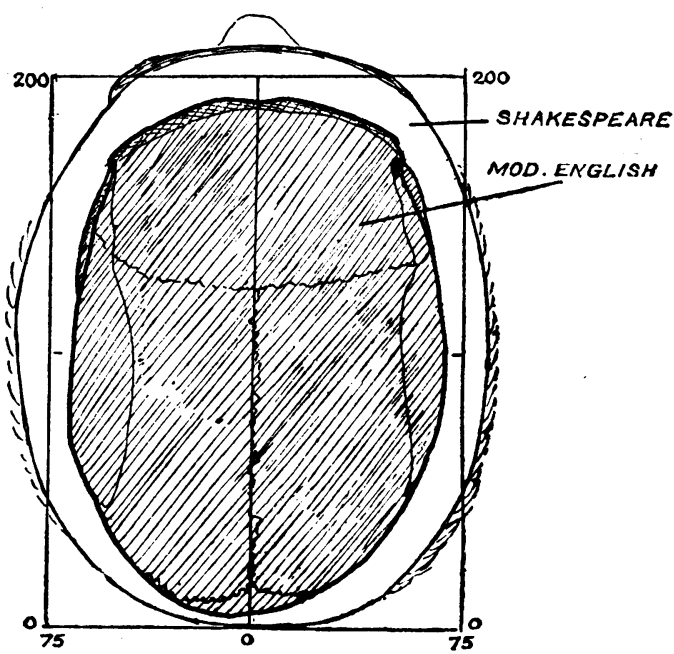
Fig. 1.-The crown of Shakespeare's head as represented in the
Stratford bust, with the corresponding view of a skull of moderate size. Both are drawn to the same scale.

crown I have placed a drawing of a skull of a modern Englishman-poised in the same position and drawn to the same scale as the Shakespearean bust. It is at once seen that there is a double contrast-one of shape and one of size. The skull of the Englishman, slightly under average dimensions, is $188 \mathrm{~mm}$. long; when covered with flesh tho head would have been $8 \mathrm{~mm}$. more-196 mm. Shake. speare's head is $212 \mathrm{~mm}$. long; his skull should have measured $204 \mathrm{~mm}$.-a long skull-reaching well towards the maximum limit of cranial length. In width, there is a much greater difference; the modern skull is $137 \mathrm{~mm}$. wide; in life, the width of the head would have measured $10 \mathrm{~mm}$. more-147 mm. The width of Shakespeare's head, as represented in his bust, is $168 \mathrm{~mm}$. His skull should have measured $158 \mathrm{~mm}$.-a wide skull-reaching well towards the limits of maximum width. In the modern skull the width represents 73 per cent. of the length; in

$\$$ I have not seen this mask, but from the drawing and measurement giren by Mr. William Page (study of Shakespeare's portraits, 1877), ; 
Shakespeare's bust the width represents 77.5 per cent. of the length. As tested by measurement the Shakespeare's head falls neither into the long-headed group nor into the round or short-headed, but within the intermediate group. Yet, when we come to examine the bust in profile all the

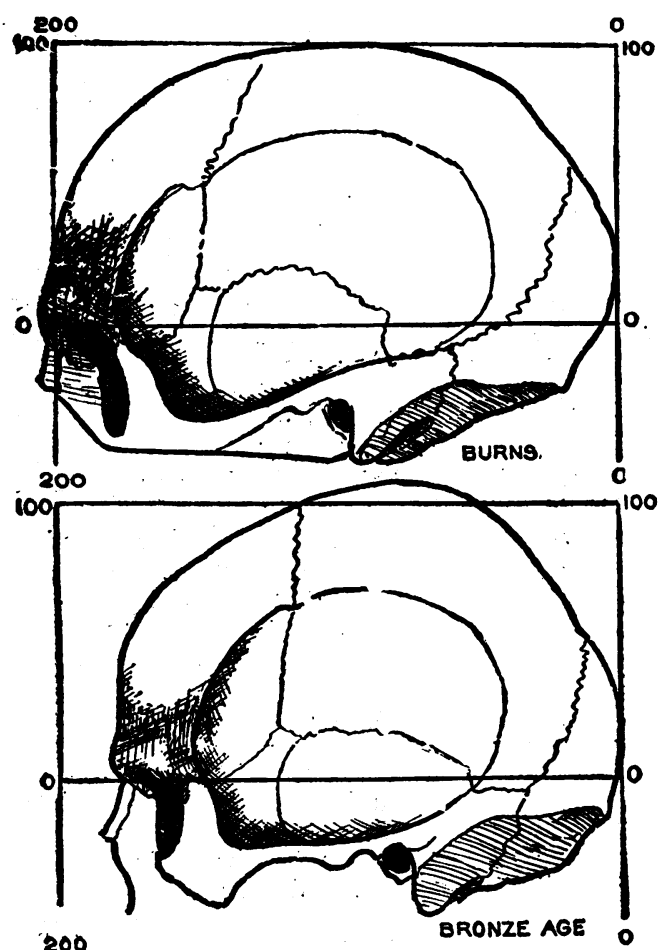

Fig. 2.-Profile of the cast of the sliull of Robert Burns, a repre sentative of the long-headed type of man, contrasted with a skul of the Bronze Age-a representative of the short type.

features which characterize the short-headed type of men become manifest.

To those who have given no special attention to the form of human heads it may seem that the short-headed and the long-headed are but variants of one type. The difference is much greater than a mere individual variation; it is a radical difference. It is fortunate for my present purpose that Robert Burns was a good repre. sentative of the long-headed type of man. In Fig. 2 the profile of lis skull is contrasted with a drawing made from the skull of the short-headed race which reached England for the first time at the close of the Neolithic period-some 2,000 years before the time of Christ. A glance at those two figures reveals an- essential difference in conformationa difference which is chiefly confined to that part of the head which lies behind the ear-holes. In Burns, the long-headed, the occiput forms a backward, projecting eminence; in the short skuil the occiput is flattened, as if it had been compressed from belind by the application of a board during infancy. There is another difference between these two types of heads: in the long head the vault is low and flat; in the round head the vault wells upward to a crown, as if the brain,

when compressed from behind, had forced up the middle part of the roof of the skull. How it has come abont that there is this radical difference between the two prevailing types of human heads in Europe we do not know; there is a secret buried here which has not been discorered as yet. All we are certain of is that the long heads are the offspring of one line of human descent-the round heads, of the type here described, of quite a different line. They must have sprung originally from a common stock.

When we come to study the Shakespeare bust in true profile, there can be no doubt as to the type of man it represents; he is depicted for us in the Stratford monument as a representative example of the short-headed

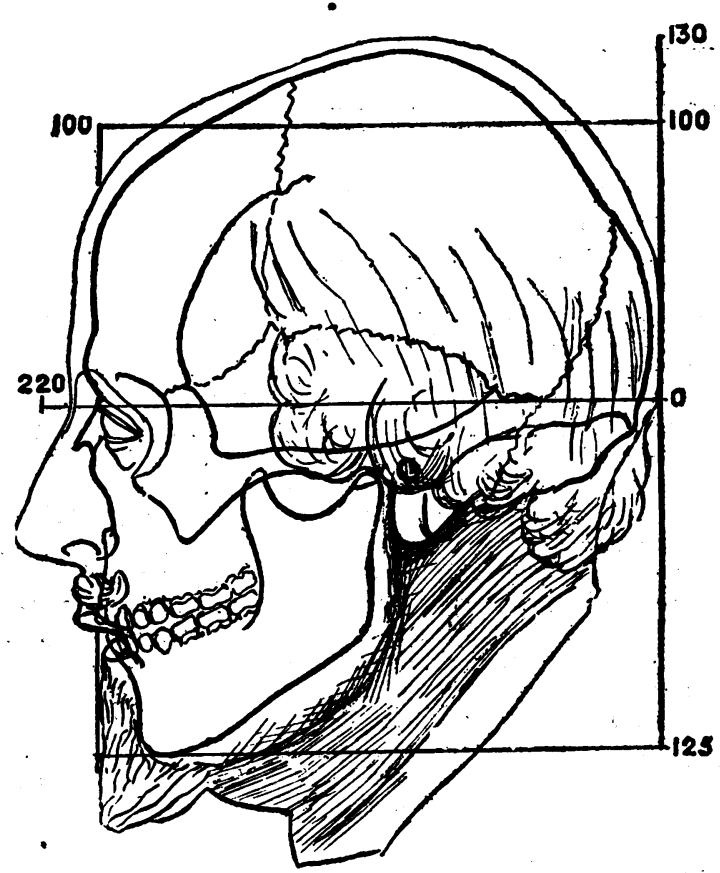

Fig. 3.-Profile of Shakespeare's bust with drawing of a skull of Bronze Age man

type. All but in one respect, the dimensions exceed those of any skull of this type lnown to me. We have seen that, in length and breadth measurements, Shakespear'e's head approaches the maximum head. This is also true of its height. The bust represents the crown as rising $150 \mathrm{~mm}$. abore the level of the ear-holes-for, although the ears are covered by the ample side-locks of hair, the position of their passages can be fixed approximately. The " auricular", lieight of the slxull-deducting $7 \mathrm{~mm}$. for the thickness of the scalp on the crown-should have measured $143 \mathrm{~mm}$. - almost a maximum amount. When I first noted those maximum dimensions of the head of Shakespeare, as portrayed by Gerrard Johnson, I was inclined to suppose the good sculptor had wished to gire the poet a head which would be in lieeping with a brain of marvellous power. Either that, or he had taken a sculptor's licence with the absolute dimensions of Shake. speare's head, and enlarged them to give to his subject that imposing dignity which increased size can give a nodelled head. The width of the forehead, at the level of the eye-brows, is represented in the Stratford bust as $120 \mathrm{~mm}$.-quite $10 \mathrm{~mm}$. beyond what a forehead, shaped as Shakespeare's is, should measure. The face is $15 \mathrm{~mm}$. longer than one would expect. If we suppose that the sculptor had added 8 to 10 per cent. to the actual measurements of the head he really portrayed, then, in every respect, the head represented in the Stratford monument as that of Shakespeare becomes a representative specimen of the short-headed 
type. I had reason, when secking for an explanation of certain features of Shakespeare's forehead, to measure Chantrey's bust of Sir Walter Scott in the National Portrait Gallery. I found in that case-and it is so in many others-the sculptor had modelled the head about 10 per cent. above the actual dimensions. I think Gerrard Johnson took a similar liberty.

In Fig. 3 I have taken the skull of a man who lived in Kent Auring the Bronze Age--the period which succeeded the Neolithicand lave done, in regard to the dimensions, what I suppose Gerrard Johnson did to Shakespeare's features-enlarged them 10 per cent. It will be seen how accurately the skull-thus en. larged-fits within the Stratford bust. From the accuracy of the fit, we may be certain that the man who wrought the Stratford bust did not portiay an imaginary head, but had before him an actual subject or model, and that subject was of the short-headed type. Was it Shakespeare's head which was portrayed? Mr. Spiel. mann assures us that the men who paid for the monument lnew Shakespeare's features and were satisfied with the likeness. They would not be satisfied, we may presume, with a radical alteiation of the shape of the liead. We cannot suppose that the sculptor gave the poet a typical short head to satisfy those who had paid him for a true

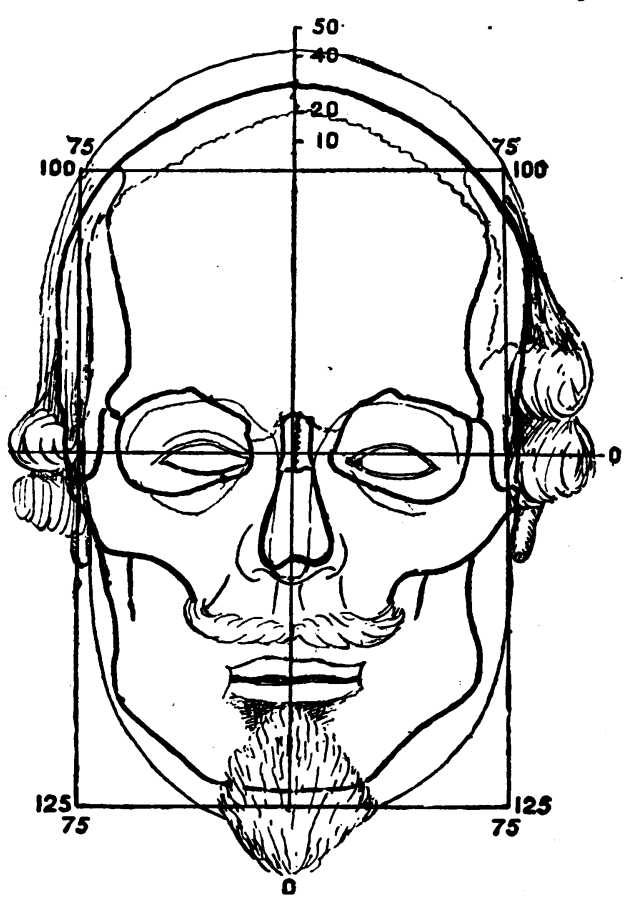

Fig. 5.-Full face view of Shakespeare's skull with similar view of a Bronze Age skull inset. The

were pushing their way westwards through Central Europe towards the coasts of the North Sea. In the Bronze period, commencing about 2,000 B.C., they began to arrive in B̉ritain. They gradually permeated every part of the country-England, Wales, Scotland, and Ireland--but at country-England, Wales, Scotland, and Ireland--but at
no period did they form the majority of our population. If I call those round-headed people Celts, I use the term in the same sense as Continental anthropologists do-in what I believe to be the true sensc. In England we speak of the Celtic fringe, and refer this fringe to the people of: Wales, the western parts of Scotland and of Ireland. The majority of the inhabitants of these parts are long-headed people; they are permeated by a roundheaded element added by the invaders of the Bronze Age. At a later date-in the Roman and Saxon periods-other additions to our population were made of the long-headed type.

Shakespeare is a descendant of the Bronze Age invaders-the true Celts. That is a remark. able fact, for it is this same short-headed stock-spread abroad in Central Europe, throughout Germany, France, and Italy-which has produced the world's finest artists.

Looking away for a minute from the question of type, it is of interest to see what size of brain the Stratford bust sug. gests for Shakespeare. If we accept the dimensions of the

It is not only from the side that the Bronze Age skull fits within Shakespeare's bust, the fit is equally good when we view its inset from above and from the front (Figs. 4 and 5): The poet is thus represented-if we allow a reduction of 10 per cent. in face and liead-as a man with facial features of average dimensions. The face, when so reduced, measures from the root of the nose to the lower margin of the chin just over $120 \mathrm{~mm}$.; its width, from the zygomatic arch of one cheek to that of the other, is a little over $130 \mathrm{~mm}$. The mean length of the face of a modern English. $\operatorname{man}$ is 120.7 mm.; its width $132 \mathrm{~mm}$. Indeed, if we presume that the sculptor added about 10 per cent. to the actual dimen: ions, then, in size of head a rd face, Shakespeare might be regarded as a representative individual of the short or round. headed type.

If there is

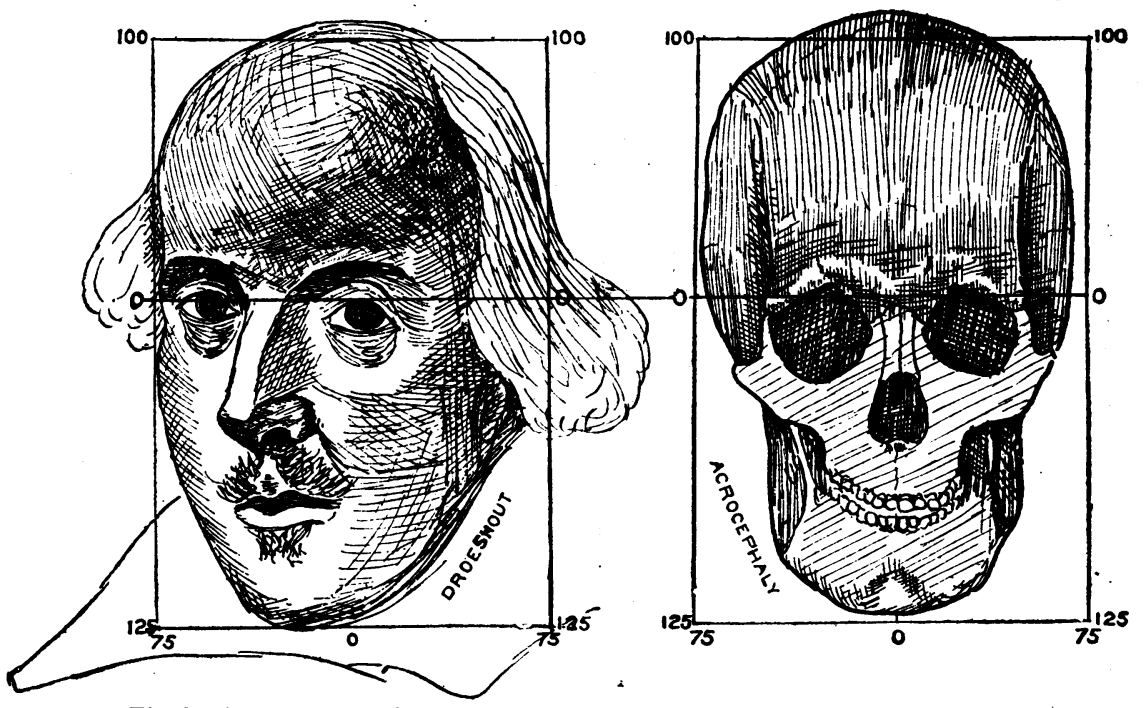

Fig. 6. A fiee copy of the Droeshout portrait compared with an acrocephalic skull. bust as real and not enlarged, we must estimate the dimensions of the skull as follows: Length. $204 \mathrm{~mm}$.; width, $158 \mathrm{~mm}$; ; auricular height, $143 \mathrm{~mm}$. Enploying one of the formulae invented by-Miss Lee and Professor Pearson for estimating the size of the brain from the dimensions of the skull, we find that Shakespeare's brain capacity was a little over 1,900 c.cm.-not an inpossible amount. Cuvier's brain eapacity was over 1,900 c.cm.; Cromwell and Byron are said to have had brain capacities weil over 2,000 c.cm. The aver. age Englishman has to be con. tent with a capacity of 1,477 ; the average Scot, according to Sir William Turner, ${ }^{5}$ with one of a cubic centimetre more. Scotland also had her invasion of round-heads d u ring the Bronze A ge, and, as in Eng. land, the type still persists, forming nearly 30 per cent. of any truth in the Stratford bust-if it represents the her population. Sir William Turner noted that the features of Shakespeare-then there is no doubt that our national poet is a product of the round-head stirp of humanity. We are certain at least that Shakespeare does not belong to the early British breed, for not a trace of a "round-head" has been found in England earlier than the age at which men began to replace their stone weapons with implements made of bronze. In the Neolithic period we have evidence that the "round-heads" people with the long heads had the larger brains. $\mathrm{He}$ found that the mean capacity for short-headed Scots is 1,469 c.cm.; for long-headed ones, 1,516. The shortheaded type has the smaller brain. If we supposeand I think we must accept the supposition-that the Stratford head has to be reduced about 10 per cent. to find the true dimensions of Shakespeare's brain, then the power of the poet's brain must be 
ascribed to quality rather than quantity. In the reduced scale, the length of the head would be $184 \mathrm{~mm}$.; width, $143 \mathrm{~mm}$; auricular height, $129 \mathrm{~mm}$; the brain capacity, 1,540 c.cm.-a rather large brain for a shortheaded man.

I shall deal briefly with Shakespeare's features as represented in the Drosshout portrait. I feel certain that it is a rather crude engraving made from some previous portrait

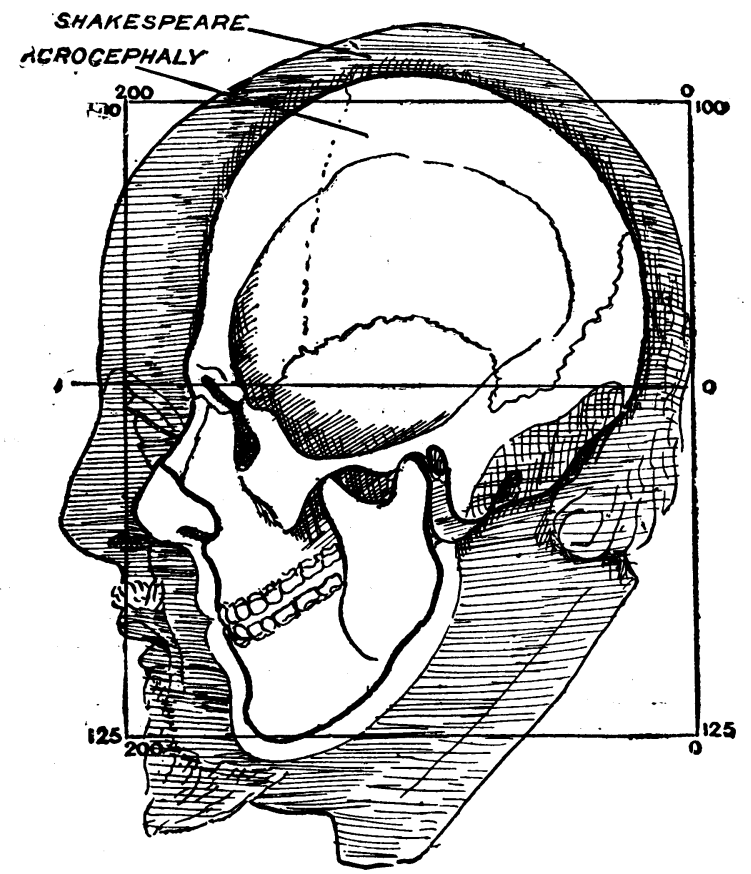

Fif. 7.-Skull showing the malformation known as acrocephal set within a profile of the Stratford bust. Both are drawn to the same scale.

or drawing which was placed at Droeshout's disposal five or six years after Shakespeare's death. Such a portrait as that known as the "Felton," now in the possession of Mr. Burdett-Coutts, might well have served as the original from which Droeshout worked. The Droeshout portrait is simply the Felton portrait with certain marks of age superadded-loss of hair and bagginess beneath the eyes. The loftiness and the modelling of the forehead in the Felion and Droeshout portraits suggests an abnormal development of Shakcspeare's head. In every race of mankind there occasionally appear individuals with remarkably high licads - individuals in whom the vault rises up to form a "tower" or "sugarloaf." The condition is due to a mal. development in the base of the skull. The front part of the base is prema turely arrested in its growth, with the result that the developing brain, in order to find room has to raise up the crown into the characteristic sugar-loaf form. The condition is now recognized as a distinct kind of maldevelopment known as acrocephaly. Sir Walter Scott was certainly the subject of this condition-at least to a mild degree. Was Shakespeare also a subject of acrocephaly?

If the Droeshout portrait be set side by side with a skull which show's the acrocephalic condition, it is seen that the vault of the skull rises higher than does the dome of the Droeshout head. When the acrocephalic skull is viewed in profile and placed within the outline of the Stratford bust, it is seen that all grounds for suspecting acrocephaly in Shakespeare disappear. The most characteristic feature of the acrocephalic head is its shortness from back to front. The head of Shakespeare's bust is relatively long. Yet, both bust and portrait show certain features with which we are familiar in acrocephalic skulls-features which do not exist in skulls of the Bronze Age type. The short

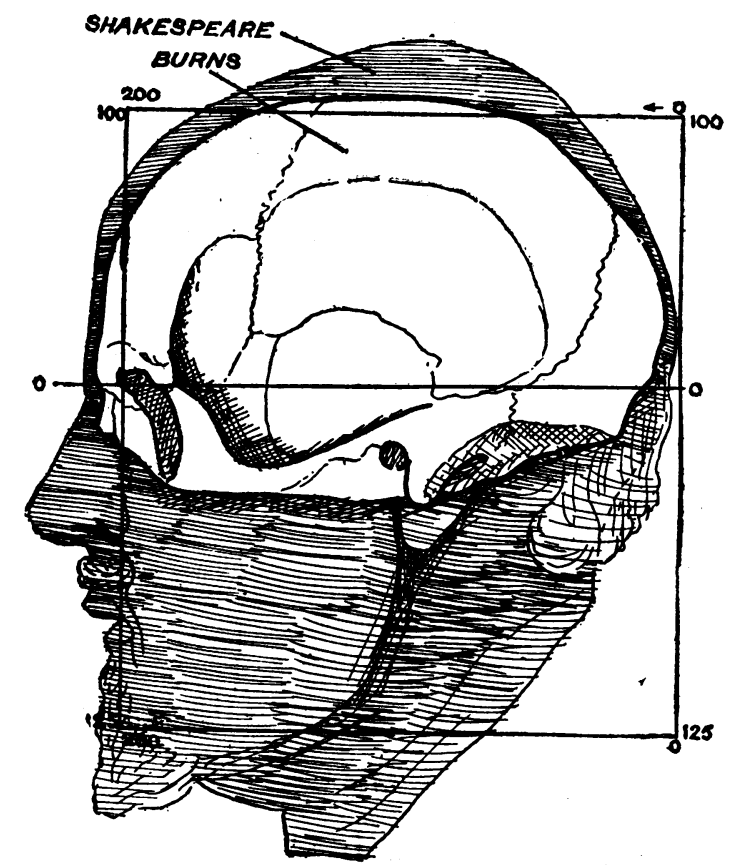

Fig. 8. - Profile of the cranial cast of Robert Burns set within a profile of the bust of William Shakespeare. Both are drawn to the same scale.

skulls of the Bronze Age period are remarkable for their prominent, well-developed eyebrow ridges. In acrocephalic skulls these ridges are not well marked, and the lower part of the forehead is often retracted or drawn inwards. But it is also true that in sensitive, less robust, delicately moulded human heads of the short type, the eyebrow ridges remain undeveloped. I am therefore of opinion that the lofty dome given to Shakespeare's head is due not to acrocephaly, or any pathological condition, but repre-

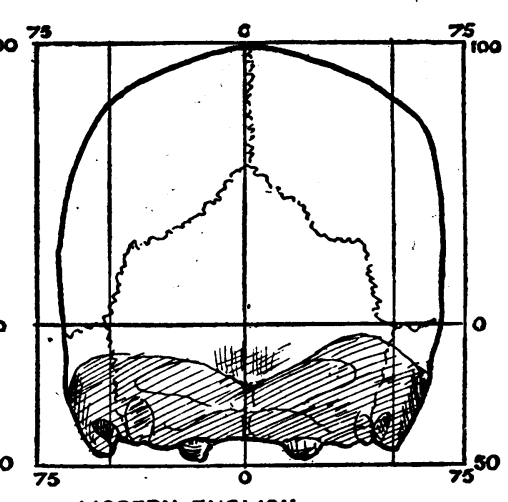

MODERN ENGLISH sents the well sprung vault and delicately moulded forehead seen in the more highly evolved of modernized round heads.

I have already mentioned that my attention was drawn to the portraits and bust of Shakespeare by the visit of $\mathrm{Mr}$. Oatway to the Museum of the College of Surgeons. It was a similar happy chance which sent certain information concerning Robert Burns my way. Less than a year ago I received a letter from Mr. Barrington Nash, well known to students of Raeburn and of Burns, informing me that he had in his possession two valuable documents relating to both his heroes. One of them was a life-size portrait of Burns by Raeburn; the other a cast of the poet's skull. I was not aware of the cxistence of either, but a visit to Mr. Nash's studio in Chelsea made me realize their great and permanent value, especially their utility for my present purposes.

That the cranial cast, which has loos presented to the 


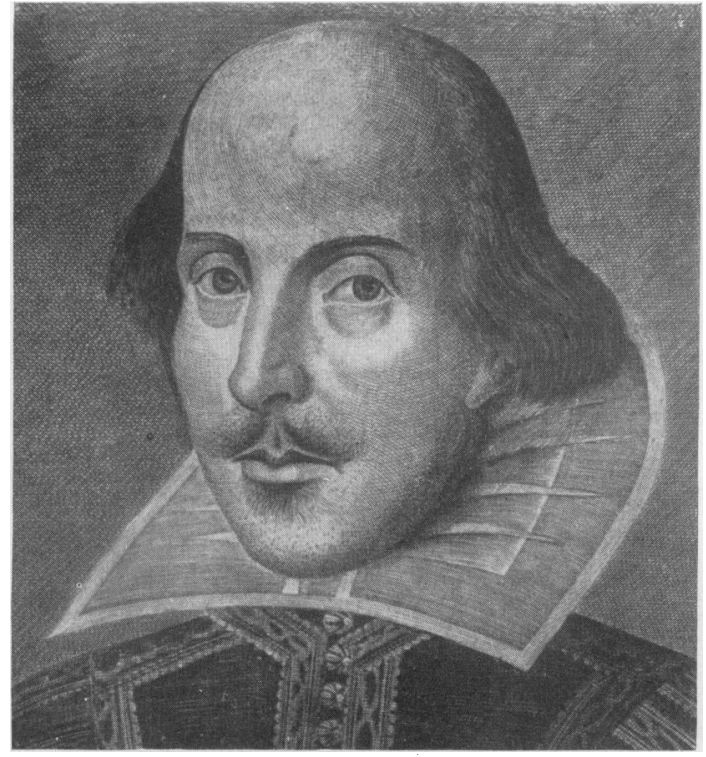

Shakespeare: Droeshout Portratt. (Photo Mansell and Co.)

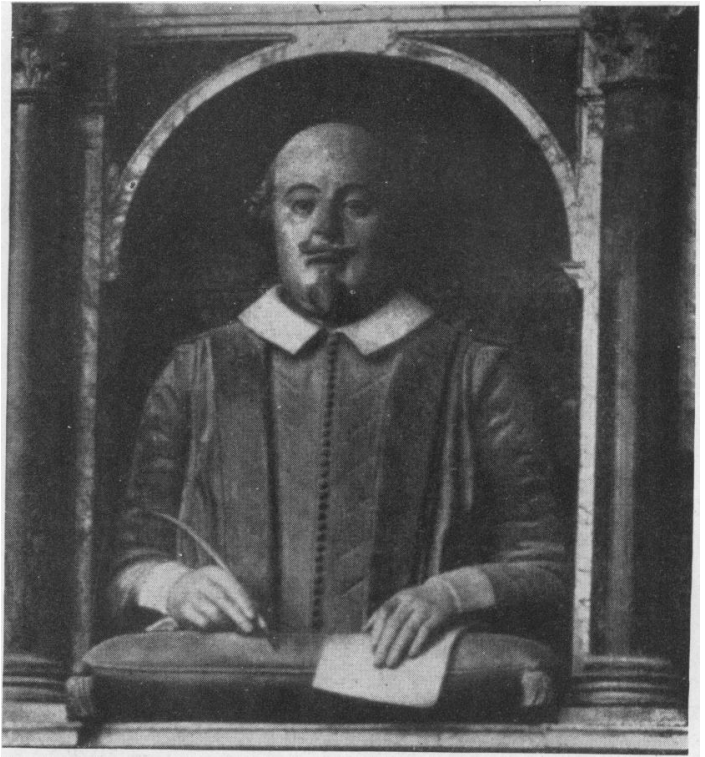

Shakespeare: Mondment at Stratford (Photo Mansell and Co.)

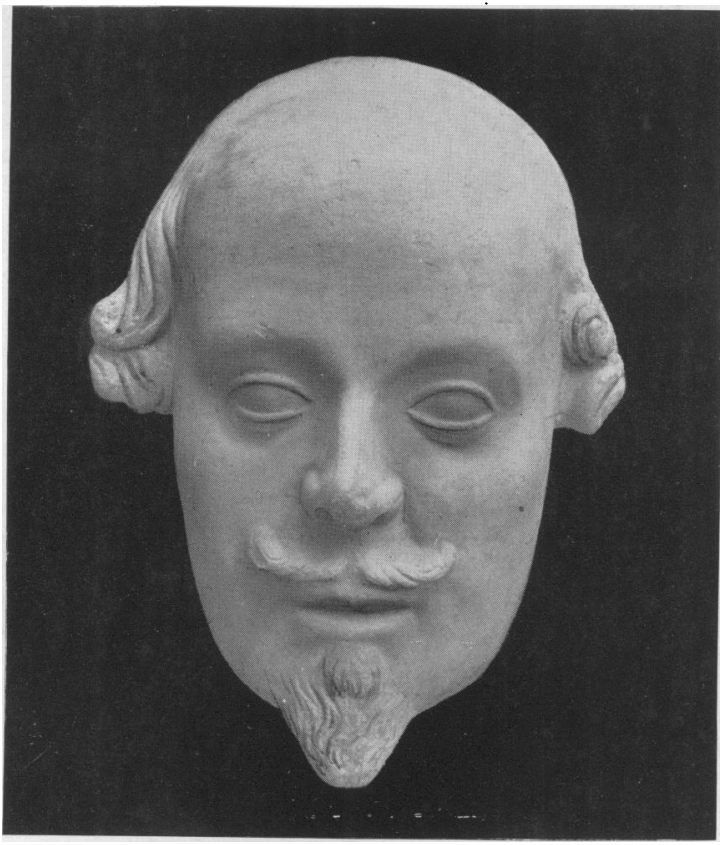

Shakespeare: The Oatway Mask.

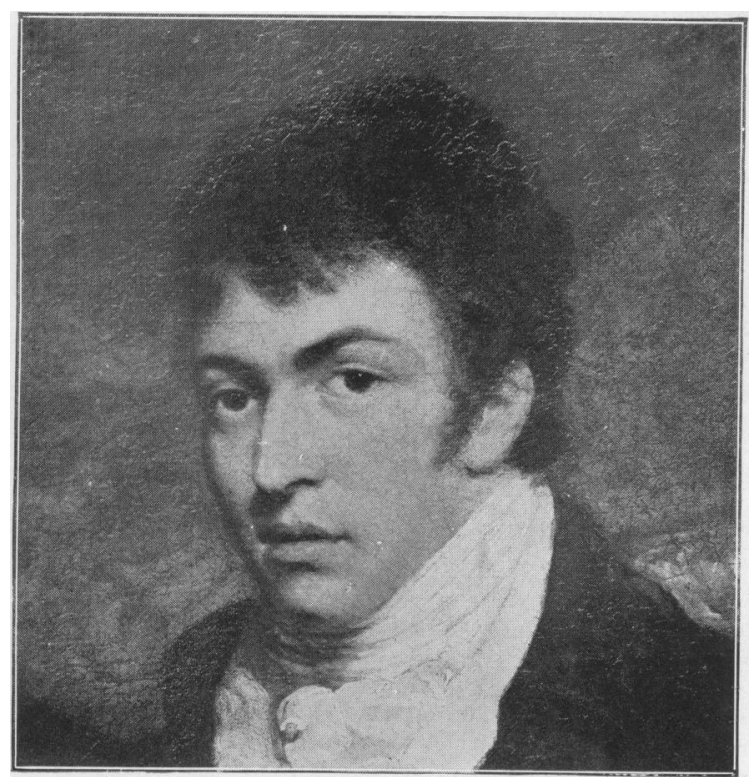

Burns : Raebunn's Portrait. (From the Sphere.)

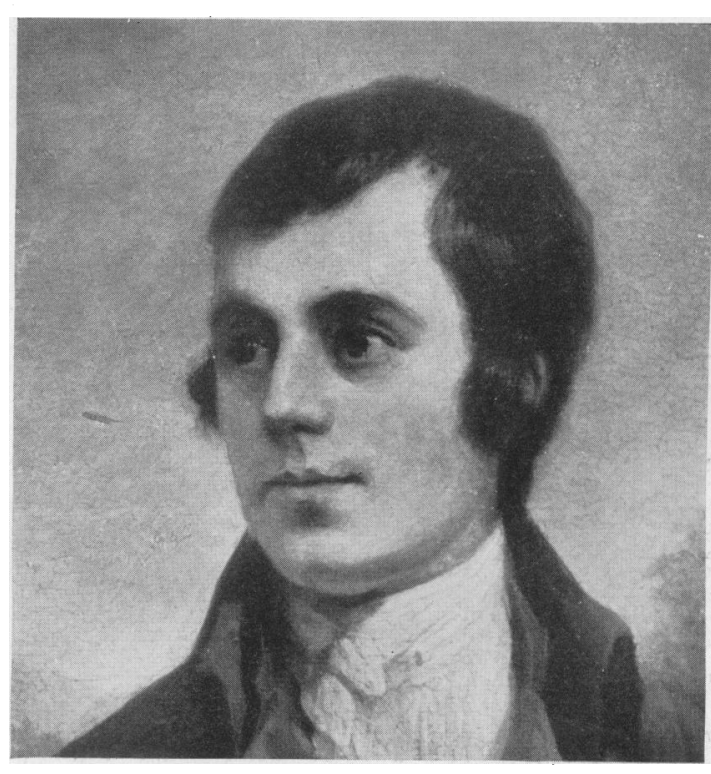
BURNS: NAsMrth's Portratt.
(National Portrait Gallery ) 
Museum of the Royal College of Surgeons by Mr. Nash, was made from the poet's skull there can be no doubt. Its history is well known. Burns died in $\mathbf{1 7 9 6}$ at the age of 37. In 1834, thirty-eight years after the poet's death, his widow, Jean Armour, died. At that time Dr. George Combe was stimulating the study of phrenology in Scotland, and when the grave was opened in 1834 Dr. Blacklock and Mr. McDiarmid, editor of the Dumfries Courier, took the opportunity of making a plaster cast of the poet's skull. Dr. George Combe published very accurate drawings of the skull, with an account of his examination, couched in the phreno. logical language of the day. The cast, as may be seen from the drawings which accompany his paper, is not complete; it includes the whole of the part which contains the brain; but, in front, stops short at the lower borders of the orbits.

The outstanding features of the skull of Robert Burns become at once apparent when we set it within the profile of Shakespeare's bust, both being drawn to the same scale and oriented in the same plane. We have seen that Shakespeare's head has been represented in large dimensions ; but as regards length the Scot's skull is the longer. Its length-206 mm. -is remarkable. In 117 skulls of Scotsmen, drawn from all parts of the country, Sir William Turner found eight which measured $200 \mathrm{~mm}$. or more in length, but the longest was $2 \mathrm{~mm}$. shorter than the poet's
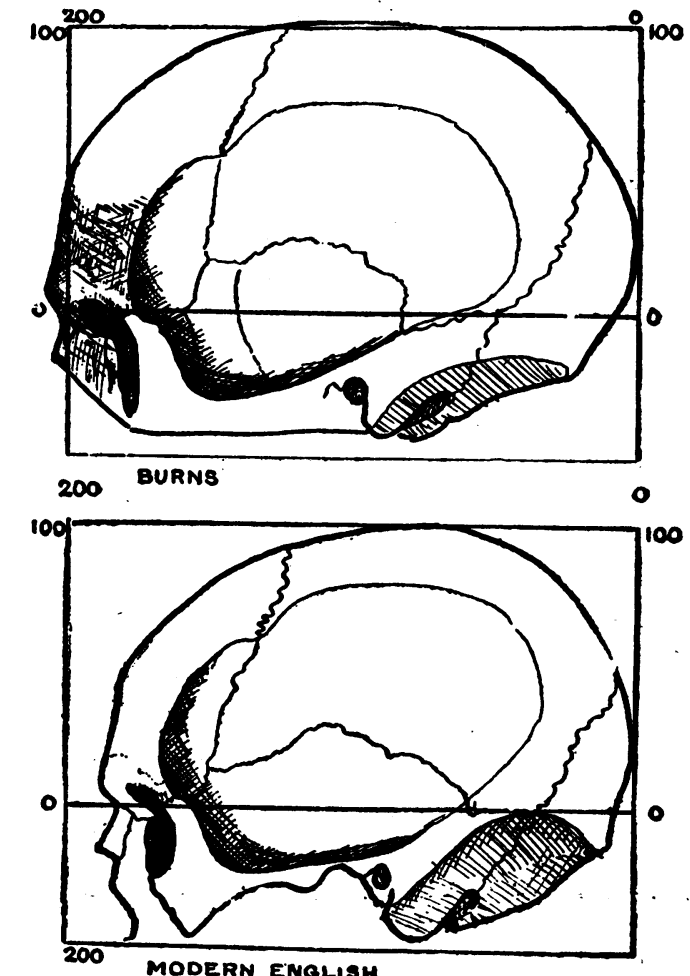

Fig. 10.-Profile of Burns's skull compared with another of the same type, but of average dimensions. Both are oriented on the same plane and drawn to the
Using the same formula as was employed in estimating the size of Shakespeare's brain, we find that the capacity of Burns's skull must have been about $1,730 \mathrm{c.cm}$. In the average Scot the capacity is 1,478 c.cm. Burns had a brain at least 200 c.cm. above the average of his country. men. The length of the cast is $206 \mathrm{~mm}$., its width $153.5 \mathrm{~mm}$. the width is 74.5 per cent. of the length. In type of skull Burns belonged to the long. headed group.

When a profile view of Burns's skull is compared with a corre. sponding view of a skull of the same type, but of rather less than average capacity, its remarkable dimensions become apparent.

There are two features of the poet's skull which are worthy of attention. One is its excessive length. As regards height, there is little difference between the type skull and the poet's. One other feature is the compression or apparent flatten. ing of the poet's skull in a vertical direction. The part of the base to which the neck was attached is shaded in both skulls drawn in Fig. 10. The area for the attachment of the poet's neck is exceptionally flat. In life, his head must have appeared to be closely set to the neck. That feature is very apparent in Raeburn's portrait of Burns. It is not so apparent in the Nasmyth portrait, for reasons to be given later.

The one feature which strikes the expert when Burns's skull is viewed from the front and contrasted with a skull of skull. In life the poet's head must havemeasured $216 \mathrm{~mm}$. $\mid$ moderate dimensions is the size of the orbits. They in length-a head of altogether exceptionad length. Ex- are of average width $(39 \mathrm{~mm}$.), but their height or vertical amination of Fig. 8 also shows that the heads of Shake. diumeter $(45 \mathrm{~mm}$.) is altogether uncommon-11 mm. more speare and Burns represent contrasted types-one is an than Sir William Turner found to be the average in skulls example of the short-headed, the other of the long. The of Scotsmen. The eyebrow ridges are strongly marked, in two national poets come of radically different stocks. In Fig. 2 I have already contrasted Burns's skull with the Bronze Age type. If the projecting occiput of the Scottish skull were pressed forwards and the vault consequently raised, it would fit comfortably within the outline of the Stratford bust (see Fig. 8).

The remarkable size of Burns's skull becomes apparent when we contrast it with a skull of ordinary dimensions. In Fig. 9 an instructive comparison is made, the contrasted skulls being examined from behind. Burns's skull is very broad-

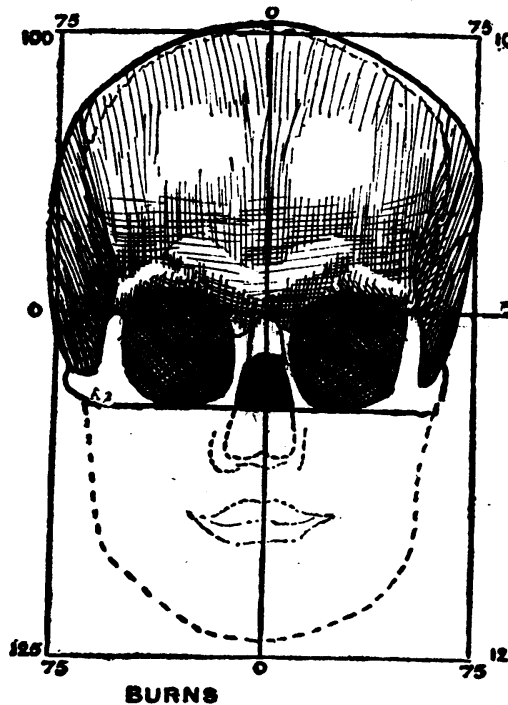

BURNS

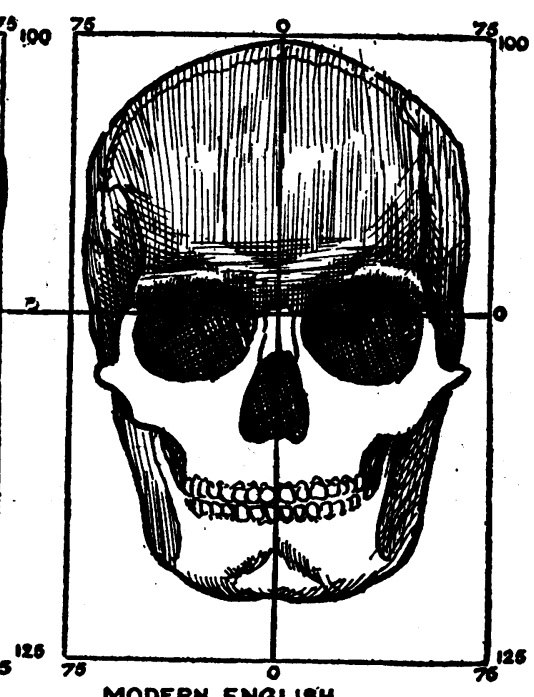

MODERN ENCLISH contrast to the slight development ind $\mathrm{i}$. cated for those of Shakespeare in the Stratford bust. The face was slightly above the average in width $(135 \mathrm{~mm}$.), and from the various portraits we may infer it had about the average length $120 \mathrm{~mm}$. Thus, while Burns's face was of average size - with long, aquiline nose, deep, capacious eyesockets, and robust eyebrow ridges-his head or cranial case was far above the average size. Sir Walter Scott was of opinion that the por. traits of Burns failed to represent the massiveness of his features. The artist $155.5 \mathrm{~mm}$., as contrasted with $137 \mathrm{~mm}$., the width probably found that if he gave full value to the head, the of the skull used for comparison. Its height is less remarkable - the vault rises $125 \mathrm{~mm}$. above the ear passages. In the skull used for comparison the auricular height is $116 \mathrm{~mm}$. From these dimensions it will be seen that the poet's brain was much above the average size. face appeared dwarfed.

Burns's skull represents an ancient type. In Fig. 12 I have reproduced a drawing of his skull from above; side by side I have placed a similar drawing of the Olmo skull. This skull was discovered deeply embedded in a 
deposit formed in the bottom of an ancient silted-up lake in the north of Italy. The animal remains found in the same deposit belong to an early part of the Pleistocene period. In size and shape the skulls of the very ancient Italian and of the Scottish poet are in close agreement. It is when we inquire into the racial origin of Burns that the value of the cranial cast as a document becomes evident. As I examined the cast, its resemblance to certain $\mathrm{skull}$ discovered and described by Professor Bryce became mani. fest. In 1896, and again in 1900, Pro. fessor Bryce explored the cairns of Arran ${ }^{6}$ systematically and thoroughly, and placed the results of his investigations on record. In two cairns-those of Torlin and Clachaig -he found the remains of a number

of human individuals; six of the skulls were sufficientiy preserved to give us an exact conception of the head form of the people who lived in Arran and interred their dead in megalithic chambered cairns. 'They were people living in the Stone Age, before bronze was introduced to Scotland. We may safely regard them as belonging to a period which ended at least 2,000 years before the time of Christ.

Now the type of skull found by Professor Bryce in the cairns of Arran is just that represented by the skull of Robert Burns.:" Of the six skulls, one was $210 \mathrm{~mm}$. long, a nother $201 \mathrm{~mm}$. In Fig. 13 one of these skulls - one of the most complete from the cairn at Clachaig-is represented. The outline of Burng's skull, drawn to the same scale, is indicated by a stippled line. There can be no doubt as to the identity of types. The poet's skull is fuller and wider than the Neolithic ones. In the Neolithic period $-4,000$ ycars or more before our timethe race to which Burns belonged lived in the country round the Firth of Clyde. We find that the ancestor of the poet who settled in Kincardine and took the name of Burness was originally Walter Campbell of Argyll. His mother, Agnes Brown, was an Ayrshire woman. Burns, then, is a direct descendant of the long-headed people who lived in England and Scotland during the Neolithic period-at least, during the later part of that period. Where the long-headed European races were evolved, where they came. from, we do not know. They were certainly of the same stock as that race which goes by the name of Iberian. When they reached Britain they found that country already populated by a long-headed and closely allied race.

* Skulls of exactly the same tyne occur in the long barrows of the South of Engtand
Thus we have in Shakespeare and Burns-in our two national poets-representatives of two of the most divergent of European stocks. If we use the term "Celt" in the same sense as it is employed on the Continent, then we must call Shakespeare a Celt-a descendant of the round. headed people who invaded England in the Bronze Age. Burns is from the western fringe, usually called "Celtic," but which in truth is pre. Celtic. $\mathrm{He}$ comes of the long-headed stock which inhabited our country before the Bronze Age-probably before the Neolithic Age dawned. Is it possible that we may explain the extraordinary dif ference in the working of their brains by the diversity of their racial origin?

Of the Raeburn portrait it is not for me to speak. That the portrait is that of Burns I have no doubt. The features of the cranial cast are manifest in the portrait. Those who have seen the Raeburn portrait have seen Burns.

ISee Illustrated London News, June 17th, 1911. 2 The Shakespeare (1911. 2 The Shakespeare 4 Mornino Post, July 5th, 1912. 5 Craniology of the People of Scotland, Trans. Roy. Soc. Edin., 1903, fol. 40, p. 547. 6 See Proc. Soc: Antiq., 1902, p. 79. 7 See an address on the portraiture of Robert Burns, delivered in the Royal Glasgow Barrington Nash (Paisley Gardner. 1896).

LAST year Grigaut described a simple test for the detection of urobilin and bilirubin in the faeces, which has been compared by Jovine with the sublimate reaction of Schmidt and Strasburger. Out of eighteen specimens the reaction was more rapid and intense than with sublimate in one-third, and in one-fifth the sublimate tcst failed, while Grigaut's test was positive. The method is to dilute a small quantity of faeces with boiling water, then add one volume of pure hydrochloric acid and a few drops of iron perchloride, diluted to 1 in 20 ; this is poured on the surface of the liquid without agitation. Two layers of liquid are Fis. 13. formed, which permit appreciation in the same tube lower layer indicates the presence of urobilin, while a green colour in the upper layer shows bilirubin; the reaction appears atrasburger's sublimate test requires twenty-four hours. The method is so simple, and the reagents so generally available, that if it should prove to be as trustworthy as Jovine affirms, it will be a valuable addition to clinical methods. We draw attention to it in order that it may be thoroughly tried.

THE Russian Minister of Public Instruction has placed $£ 10,000$ at the disposal of the St. Petersburg Academy of Sciences, to be devoted to the search for radio-active ores in different parts of the empire. 